Nippon Suisan Gakkaishi $\quad$ 83(2), $242(2017)$

\title{
ミニシンポジウム記録 水産教育の現場から次世代育成を考える
}

\section{4. 水産・海洋系高校教員減少を現場から考える 一水産科教諭が語るその魅力とは一}

長岡智子

京都府立海洋高等学校

4. Charm of work as a fisheries and marine high school teacher

Tомоко NAGAOKA

Kyoto Prefectural Fisheries and Marine High School, Miyazu, Kyoto 626-0074, Japan

\section{1. はじめに}

水産・海洋系高等学校は全国に 46 校あり, 約 10,000 人の高校生が水産・海洋関連産業を牽引する人材を目指 して, 教科「水産」を履修している。一方, 教員の大量 退職は今後も数年間続くと見られ, 水産・海洋系高校で も教員不足が懸念されており, 高い専門性を備えた優秀 な人材の安定確保が急務である。現状を踏をえ, 水産・ 海洋系高校の存在と教育実践の一端, そして水産科教員 の魅力を知っていただく機会にしたい。

\section{2. 水産・海洋系高校とは}

専門学科では, 教室で行う座学の他に, 週 $1 \sim 3$ 回設 定されている実習科目がある。地域の実態や学科・コー スの特色等に応じた課題を設定し, 各科目で習得した知 識や技能を有機的に活用して, 問題解決に向けた学習を 展開している。また, 職業資格取得のための授業・実習 等もある。本校は「海のスペシャリスト」育成を目指す 近畿唯一の水産・海洋系単独専門高校である。3 学科 4 コースを設置し, 文部科学省「環境のための地球規模の 学習及び観測プログラム (グローブ) 」, 京都府教育委員 会「スペシャリストネットワーク京都」等の指定を受け, 関連機関や地域との連携の下, 専門的な研究活動を推進
している。

\section{3. 水産科教員の魅力}

各都道府県に設置されている水産・海洋系高校は約 1 校であり, 教諭として採用された場合, 異動することが ほとんぞない。それゆえ, 自らの教育活動を長期にわ たって考え, 計画的に実践に移すことができる。本稿で はその魅力のうち， 2 点を挙げる。

1 点目は, 学校現場に居ながらにして, 自らの専門分 野を活かして，地域の活性化に貢献できることである。 水産・海洋系高校の教育実践は, 校内に留まらず, 地元 産業や外部機関, 他校種等との協働を通して充実し, 深 化する。生徒と共に地域の課題に取り組み, 新たな発見 や経験を共有したり, 高校生の柔軟な発想や行動力が課 題解決につながったりしているといった教員ならではの 感動もある。取組を通して生徒の自己有用感が育まれ, 地元水産業の担い手として逞しく成長する姿を間近で見 られるのも, この職業ならではの魅力である。

2 点目は，生徒を卒業後も見守り，交流できることで ある。本校で身に付けた知識や技能を活かし, 地元で就 職したり, 上級学校進学後に地域や関連産業等で活躍し たりする卒業生の様子を知ることは，教員にとって最も 嬉しく, 誇らしいことの1つである。また, 卒業生か ら得られる情報は, 時代や地域のニーズを知り, 自らの 教育実践の在り方を見直すきっかけになる。さらに，生 徒の職業観や勤労観を育むためのキャリアモデルとして も貴重な存在である。

\section{4. おわりに}

教育とは生徒と未来を語ることと言われる。日本の水 産業は様々な問題に直面している。しかし, その解決に 向けて懸命に取り組む高校生の姿は, 私たちに使命感を 超えたやりがいを授けてくれる。 